\title{
Interactions among Stock Price and Financial Ratios: The Case of Turkish Banking Sector
}

\author{
Ekrem Meriç ${ }^{1}$, Melik Kamışl1 ${ }^{2}$, Fatih Temizel ${ }^{3}$ \\ ${ }^{1}$ Lecturer, Open Education Faculty, Anadolu University, Eskişehir, Turkey \\ ${ }^{2}$ Assistant Professor, Department of Banking and Insurance, Bozüyük Vocational School, Bilecik Şeyh Edebali \\ University, Bilecik, Turkey \\ ${ }^{3}$ Associate Professor, Faculty of Economics and Administrative Sciences, Anadolu University, Eskişehir, Turkey \\ Correspondence: Melik Kamışlı, Department of Banking and Insurance, Bozüyük Vocational School, Bilecik Şeyh \\ Edebali University, 11300 Yeşilkent Mh. 1.Cd., Bozüyük, Bilecik, Turkey.
}

Received: October 16, 2017

Accepted: November 1, $2017 \quad$ Available online: November 1, 2017

doi:10.11114/aef.v4i6.2755

URL: https://doi.org/10.11114/aef.v4i6.2755

\begin{abstract}
One of the important variables for investors is the price of stocks and so that the variables that affect the price of the stocks. There are many indicators and methods such as fundamental and technical analysis that investors can use in valuing these instruments. Fundamental analysis, and financial ratios are tools that are generally used in investments process. Especially price-earnings ratio and dividend yield ratio are traditional financial ratios which are used to forecast the performance of the stock. In this context, the purpose of this study is to analyze the relationships between the price, price-earnings ratio and dividend yield ratio of the companies that are listed at BIST Banking sub-sector. In this context, in line with the aim of the study monthly price, price-earnings ratio and dividend yield ratio of VAKBN; ISCTR; HALKB; GARAN; AKBNK stocks between 2008M10-2017M3 will be analyzed by VAR methodology. Results show that the relationships between the abovementioned variables changes in size and direction from bank to bank.
\end{abstract}

Keywords: portfolio management, financial ratios, banking stocks

\section{Introduction}

Investors make decision based on their information level and risk perception while investing in financial assets. Stock investors generally use methods such as fundamental analysis and technical analysis following many indicators. Also, it is very practical to calculate financial ratios and use them in investment process. But, despite the ease of calculation there is a complicated relationship between price and financial ratios. In literature and practice many different ratios are used in determining stock price. However, especially price-earnings ratio and dividend yield ratio come to the forefront in estimating stock performance.

Academicians in theory and security analysts, portfolio managers, investment advisors and individual investors in practice often use price-earnings ratio and dividend yield ratio in stock selection process. It is expected the stock which has low price-earnings ratio to provide higher return in the future period. Dividend yield shows how much dividend the company pays in proportion to stock price. The ratio is often used even though it does not consider the earning that may arise from the increase in value of the share in addition to dividend yield.

Price-earnings ratio and dividend yield ratio provide ease of calculation and interpretation. With this feature, they are generally accepted as one of the fundamental indicators by individual investors besides markets professionals such as security analysts, portfolio managers and investment advisors. In the study, potential of price-earnings ratio and dividend yield ratio in explaining the stock price changes is investigated. If they have potential to explain the price changes, then investors can evaluate efficiency of their investments. This feature reveals the widespread impact of the study. Empirical findings on one hand present the opportunity of increasing the decision making efficiency to the investors, on the other hand they prove the practicality of the findings of academic researches. To this end, in the study it is aimed to obtain theoretical and practical benefits by the detailed analysis of the relationships between stock price, price-earnings ratio and dividend yield ratio of the companies listed at Borsa Istanbul (BIST) Banking sub-sector. 
The rest of the study is organized as follows: in the next section the studies that used the same variables and the methodology are examined. Later, the variables and the methodology that are used in the study are presented. In section 4 , descriptive statistics and analysis results of the relationships between stock price and financial ratios are given. In section 5 , conclusions are presented.

\section{Literature Review}

In finance literature the relationships among stock price/return, company performance and financial ratios are investigated with different econometric methods for different markets. In this section, the studies which analyze the relationships among especially price-earnings ratio, dividend yield ratio and price/return are examined based on the purpose of the study.

The systematic effect of price-earnings ratio is firstly revealed by Basu (1977). Basu, analyzed the data of 1400 companies listed at NYSE industrial sector by regression analysis for the period 1956-1971. The study shows that the portfolios which have low price-earnings ratio provide higher return. This study is also important for the literature in terms of being the first study which researched the relationships between stock price and price-earnings ratio with regards to "Efficient Market Hypothesis".

Tse (2002) studied on the relationships between among dividend yields, stock returns and price-earnings ratio of the real estate companies, for the period 1991 - 2000. Multiple regression method was used in the study, and results show that fast growth in stock prices and slow growth in dividend yields cause increase in price-earnings ratio. Similarly, Omran and Ragab (2004) examined the relationships between stock returns and financial ratios. They used different methods in to analyze the data of 46 Egyptian firms for the period 1996 - 2000, and found that financial ratios have effects on stock returns. Differently from the literature, Carlson, Pelz and Wohar (2002) applied structural break tests to the dividend yield and price-earnings ratio, and indicated to negative effect of high inflation.

Bhargava and Malhotra (2006) investigated the interactions between stock returns and financial ratios belong to S\&P 500, MSCI World, MSCI Europe and EAFE indexes for the period 1980 - 2000. Johansen Cointegration Test, VECM and VAR analysis results show that price-earnings ratio does not have effect on stock return. Durré and Giot (2007) similarly used different methods in their study. In the study, they analyzed the relationships among stock prices, earnings and long-term government bond yields, and found that changes in long-term government bond yields cause short-term effects on stock prices.

Aras and Yllmaz (2008) aimed to estimate the stock returns by using price-earnings ratio, dividend yield and market to book value ratio. The data belongs to 12 emerging stock markets analyzed by Multi-Regression models, and results proved that the variables have different explanatory power; market to book value ratio, dividend yield and price-earnings ratio from highest explanatory power to lowest respectively. In order to determine the effects of company size, variability of earnings, variability in market price, debt-equity ratio, dividend payout ratio and growth rate of market price on price-earnings ratio, Bhadu and Warne (2009) researched the Bombay stock market for the period 2001 - 2007. They applied Multiple Regression models and proved that the most important factor affecting the price-earnings ratio is the company size.

By using VECM model, Al-Mwalla, Al-Omari, and Ayad (2010) examined the relationships among stock returns, total assets, dividend yields and price-earnings ratio, and long-run relationship between the variables was determined. Al-Shubiri (2010) investigated the interactions between stock price, financial ratios and macroeconomic factors for the 14 commercial banks listed at Amman Stock Exchange. The analyses made for the period 2005 - 2008 show that there are positive relations between market price and net asset value per share, and market price of stock dividend percentage and gross domestic product. Also, it is found negative relationship between inflation and lending interest rate.

Sezgin (2010) analyzed the relationships among stock return, dividend yield and price-earnings ratio of ISE 100 Index by Johansen cointegration test, error-correction model and Granger causality test. According to the empirical results there are short, long run relationships and unidirectional causality among the variables. Findings also indicate that in the long-run stock return has negative effect on price-earnings ratio while dividend yield has positive effect. In their study, Gupta and Modise (2012) estimated the stock return movements in South Africa stock market by determining the relationships between price/dividend, price-earnings ratio and stock price with linear regression and Monte Carlo simulation.

Delen, Kuzey, and Uyar (2013) studied on the company performance based on 32 financial ratios. Analysis period covers 2005 - 2011, and companies were selected from Borsa Istanbul. The study which use decision tree and sensitivity analysis reveals that Earnings before Tax-to-Equity Ratio and Net Profit Margin ratios are important in determining company performance. Arslan and Zaman (2014) examined the effects of financial ratios on stock return by panel data analysis, for the period 1998-2009. Results show that price earnings ratio and company size have positive effect on stock price, and there is negative relationship between dividend yield and stock price. In the study of Lutfi and Arsitha 
(2016) the relationships between price-earnings ratio and financial ratios were analyzed for Jakarta Islamic Index. F-test and $\mathrm{t}$-test were used in the study, and it is found that total assets and dividend yield ratio have important effects on price-earnings ratio.

When the studies in the literature are considered, it is seen that there are too many studies that analyze the relationships among price-earnings ratio, dividend yield ratio and price/return by different methods. With this study we aim to present information to the investors who are interested in BIST Banking sub-sector by analyzing the relationships in different dimensions with current dataset.

\section{Data and Methodology}

The main purpose of this study to analyze the relationships between stock price, price-earnings ratio (PE) and dividend yield ratio (DY) of the companies listed at BIST Banking sub-sector. In this context, the fundamental hypothesis of the research can be expressed as follows;

$\mathrm{H}_{0}$ : There is no relationship between stock price, price-earnings ratio and dividend yield ratio of the companies listed at BIST Banking sub-sector.

$\mathrm{H}_{1}$ : There is relationship between stock price, price-earnings ratio and dividend yield ratio of the companies listed at BIST Banking sub-sector.

In the study 102 monthly stock price, price-earnings ratio and dividend yield ratio of Akbank A.Ş. (AKBNK), Türkiye Garanti Bankası A.Ş. (GARAN), Türkiye Halk Bankası A.Ş. (HALKB), Türkiye İş Bankası A.Ş. (ISCTR) and Türkiye Vakıflar Bankası T.A.O. (VAKBN) companies, between October 2008 - March 2017 are used. The stock prices and the financial ratios that are used in the study are gathered from Thomson Reuters Datastream.

Within the scope of the study we focused data of 5 banks listed at BIST 30 index. The reason why we chose BIST 30 is because the capitalization ratio of the index is high and it has high ability to represent the general index. Additionally, there is no difference in terms of meaning and interpretation between the analyzed financial ratios, because these five banks operate in the same subsector and use the same accounting system.

In the study based on the purpose stated above the relationships between stock price and financial ratios are analyzed Vector auto regression (VAR) model. VAR model which is proposed by Sims (1980) give the opportunity of investigating the dynamic relationships between the variables in different dimensions, and so it is used in time series analyses frequently. According to Sims (1980) VAR analysis aims to determine the relationships between the variables rather than parameter estimation.

Bivariate VAR model can be written as follows:

$$
\begin{gathered}
\mathrm{y}_{\mathrm{t}}=\mathrm{a}_{1}+\sum_{\mathrm{i}=1}^{\mathrm{p}} \mathrm{b}_{1 \mathrm{i}} \mathrm{y}_{\mathrm{t}-\mathrm{i}}+\sum_{\mathrm{i}=1}^{\mathrm{p}} \mathrm{b}_{2 \mathrm{i}} \mathrm{x}_{\mathrm{t}-\mathrm{i}}+\mathrm{v}_{1 \mathrm{t}} \\
\mathrm{x}_{\mathrm{t}}=\mathrm{c}_{1}+\sum_{\mathrm{i}=1}^{\mathrm{p}} \mathrm{d}_{1 \mathrm{i}} \mathrm{y}_{\mathrm{t}-\mathrm{i}}+\sum_{\mathrm{i}=1}^{\mathrm{p}} \mathrm{d}_{2 \mathrm{i}} \mathrm{x}_{\mathrm{t}-\mathrm{i}}+\mathrm{v}_{2 \mathrm{t}}
\end{gathered}
$$

Where, $\mathrm{p}$ is the lag length, $\mathrm{v}$ is the error term that has zero-mean, constant variance, normal distribution and zero covariance with its lagged values (Gujarati \& Porter, 2009).

Steps of the analysis are as follows;

1. Investigating the stationarity of the variables, which will be included to the model, by unit root tests.

2. Determining the optimal lag length based on the information criteria.

3. Estimating VAR model and checking stability conditions by diagnostic tests.

4. Determining the relationships between variables by Granger causality tests, impulse-response functions and variance decompositions.

\section{Empirical Results}

Prerequisite for applying VAR model is stationary of the variables that will be used in the analysis. Therefore, firstly stationarity of the series is tested. On the other hand, descriptive statistics present valuable information about the variables. In this context, unit root test results and descriptive statistics of price, price-earnings ratio and dividend yield ratio of selected companies listed at BIST Banking sub-sector are given at Table 1. 
Table 1. Descriptive Statistics

\begin{tabular}{lcccccccc}
\hline & Mean & Med. & S.D. & Skew. & Kurtosis & Jarque-Bera & ADF & PP \\
\hline AKBNK & 7,24 & 7,56 & 1,40 & $-1,22$ & 4,73 & $38,12^{*}$ & -2.51 & $-2,50$ \\
GARAN & 7,17 & 7,51 & 1,75 & $-1,32$ & 4,83 & $44,03^{*}$ & $-2.63 * * *$ & $-2,61^{* * *}$ \\
HALKB & 11,9 & 11,9 & 3,49 & $-0,31$ & 3,27 & 1,91 & -2.29 & $-2,27$ \\
ISCTR & 4,89 & 4,95 & 1,11 & $-0,5$ & 3,29 & 4,52 & $-2.67 * * *$ & $-2,61^{* * *}$ \\
VAKBN & 3,95 & 4,06 & 1,06 & $-0,79$ & 4,06 & $15,39 *$ & -2.23 & $-2,25$ \\
AKBNK_DY & 1,92 & 1,82 & 0,81 & 3,74 & 17,77 & $116,5 *$ & $-5.26 *$ & $-5,58^{*}$ \\
GARAN_DY & 1,43 & 1,65 & 0,74 & $-0,62$ & 3,14 & $6,62^{* *}$ & -1.28 & $-1,37$ \\
HALKB_DY & 2,64 & 1,95 & 3,02 & 4,56 & 22,96 & $204,6 *$ & $-5.79 *$ & $-8,58^{*}$ \\
ISCTR_DY & 2,84 & 2,93 & 1,03 & 0,24 & 3,91 & 4,48 & $-4.23^{*}$ & $-3,26 * *$ \\
VAKBN_DY & 1,09 & 0,89 & 0,93 & 2,92 & 11,81 & $474,9 *$ & $-5.73 *$ & $-6,09 *$ \\
AKBNK_PE & 10,2 & 9,5 & 2,62 & 1,01 & 3,53 & $18,49 *$ & $-2.99 * *$ & $-2,62^{* * *}$ \\
GARAN_PE & 8,80 & 8,81 & 2,05 & $-0,85$ & 4,73 & $24,89 *$ & $-3.43^{* *}$ & $-3,45 * *$ \\
HALKB_PE & 7,72 & 7,31 & 2,19 & 0,94 & 3,77 & $17,51 *$ & -2.11 & $-2,25$ \\
ISCTR_PE & 7,41 & 7,08 & 1,53 & 0,79 & 2,87 & $10,70^{*}$ & $-3.24 * *$ & $-2,78^{* * *}$ \\
VAKBN_PE & 7,17 & 6,91 & 2,06 & 0,53 & 3,58 & $6,19 * *$ & $-3.27 * *$ & $-2,93 * *$ \\
\hline
\end{tabular}

When Table 1 is analyzed it is seen that the stocks which have the highest mean in terms of price are HALKB, AKBNK and GARAN respectively. However, the stocks that have highest standard deviation are HALKB and GARAN. On the other hand, ISCTR and HALKB are the stocks that have the highest dividend yield ratio. But, dividend yield ratio of HALKB has the highest standard deviation among the dividend yield ratios of the all stocks. The stock which has the highest average price-earnings ratio is $\mathrm{AKBNK}$, and in analogy to statistics of dividend yield ratio, price-earnings ratio of AKBNK has the highest standard deviation among the price-earnings ratios of the all stocks.

Prices of all the stocks, dividend yield ratio of HALKB and dividend yield ratio of GARAN have negative skewness values. Also, kurtosis values of all variables except price-earnings ratio of ISCTR are higher than 3. This indicates that series move away from normal distribution based on the financial shocks that occurred in the analysis period. After computing descriptive statistics, stationarity of the series is checked, because variables in the VAR model must be stationary (Lütkepohl, 2005). In order to test the stationarity of the series, Augmented Dickey Fuller (1981) and Phillips-Perron (1998) unit root tests that are frequently used in the literature are applied to the variables. According to the unit root test results, all of the series are stationary except price of AKBNK, HALKB and VAKBN stocks, dividend yield ratio of GARAN and price-earnings ratio of HALKB.

In the next step, the relationships between the variables are analyzed with VAR model in line with the purpose of the study. In this context, firstly optimal lag lengths of the model are determined based on the information criterias. After estimating the model, it must be tested that if the estimated model is stationary or not. Diagnostic test results of the selected VAR models are presented at Appendix A and Appendix B.

After determining the appropriate VAR model, Granger Causality tests are applied to determine whether the variables included in the model have interrelations and to determine the direction of the relationships, and the results are given in Table 2 .

Table 2. Granger Causality Test Results

\begin{tabular}{lclc}
\hline AKBNK_DY $\neq>$ AKBNK & $\mathbf{3 4 . 9} *$ & HALKB_PE $\neq>$ HALKB_DY & $\mathbf{2 7 . 8}$ \\
AKBNK_PE $\neq>$ AKBNK & $\mathbf{3 1 . 7} *$ & HALKB $\neq>$ HALKB_PE & 9.05 \\
AKBNK $\neq>$ AKBNK_DY & 6.63 & HALKB_DY $\neq>$ HALKB_PE & 13.1 \\
AKBNK_PE $\neq>$ AKBNK_DY & 6.46 & ISCTR_DY $\neq>$ ISCTR & $\mathbf{3 7 . 4}$ \\
AKBNK $\neq>$ AKBNK_PE & 11.2 & ISCTR_PE $\neq>$ ISCTR & $\mathbf{9 8 . 7}$ \\
AKBNK_DY $\neq>$ AKBNK_PE & $\mathbf{1 9 . 9} * *$ & ISCTR $\neq>$ ISCTR_DY & 3.20 \\
GARAN_DY $\neq>$ GARAN & $\mathbf{1 1 . 8} * * *$ & ISCTR_PE $\neq>$ ISCTR_DY & 7.84 \\
GARAN_PE $\neq>$ GARAN & $\mathbf{9 2 . 9 *}$ & ISCTR $\neq>$ ISCTR_PE & 11.1 \\
GARAN $\neq>$ GARAN_DY & 3.41 & ISCTR_DY $\neq>$ ISCTR_PE & 12.6 \\
GARAN_PE $\neq>$ GARAN_DY & 4.80 & VAKBN_DY $\neq>$ VAKBN & 9.18 \\
GARAN $\neq>$ GARAN_PE & 8.47 & VAKBN_PE $\neq>$ VAKBN & $\mathbf{9 8 . 6}$ \\
GARAN_DY $\neq>$ GARAN_PE & 2.89 & VAKBN $\neq>$ VAKBN_DY & $\mathbf{2 5 . 7 * *}$ \\
HALKB_DY $\neq>$ HALKB & 9.04 & VAKBN_PE $\neq>$ VAKBN_DY & $\mathbf{2 3 . 4 * *}$ \\
HALKB_PE $\neq>$ HALKB & $\mathbf{3 8 . 5 *}$ & VAKBN $\neq>$ VAKBN_PE & 10.9 \\
HALKB $\neq>$ HALKB_DY & $\mathbf{3 6 . 5 *}$ & VAKBN_DY $\neq>$ VAKBN_PE & 9.25 \\
\hline
\end{tabular}

The symbol $\mathrm{X} \neq>\mathrm{Y}$ means that $\mathrm{X}$ does not cause $\mathrm{Y} . *, * *, * * *$ shows significance at $1 \%, 5 \%$ and $10 \%$ level.

As can be seen from Table 2, different causality relationships are determined between the financial ratios of the banks. 
But, according to the Granger causality test results, there is no mutual causality relationship between the financial ratios of the banks. The identified causality relationships are generally unidirectional. AKBNK dividend yield ratio and price-earnings ratios are cause of stock price, and dividend yield ratio is cause of price-earnings ratio. Similarly, GARAN dividend yield ratio and price-earnings ratios are cause of stock price. HALKB price-earnings ratio is cause of stock price, and stock price and price-earnings ratio are cause of dividend yield ratio. Similarly, VAKBN price-earnings ratio is cause of stock price, and stock price and price-earnings ratio are cause of dividend yield ratio. Finally, ISCTR dividend yield ratio and price-earnings ratios are cause of stock price, and there is no interrelation between dividend yield ratio and price-earnings ratio of GARAN and ISCTR.

In the next step of the study, the effects of the shocks that occurred in error terms of the variables in the model on the other variables are determined by impulse-response functions. Graphics of the impulse-response functions are presented at Appendix C. When the graphics are examined it is seen that although the duration of the responses are different the variables generally react negatively to the shocks.

The response of AKBNK dividend yield ratio to the one standard deviation shock in the AKBNK price-earnings ratio is negative for six months. Similarly, response of AKBNK price-earnings ratio to the one standard deviation shock in the AKBNK dividend yield ratio is negative until two months. The response of GARAN price-earnings ratio to the one standard deviation shock in the GARAN dividend yield ratio is negative for four months.

The response of HALKB dividend yield ratio to the one standard deviation shock in the AKBNK price-earnings ratio is negative for three months, and response of HALKB stock price ratio to the one standard deviation shock in the HALKB dividend yield ratio is negative for two months. On the other hand, response of ISBANK dividend yield ratio to the one standard deviation shock in the ISBANK price-earnings ratio is negative for six months, and vice versa. However, response of price to the one standard deviation shock in dividend yield ratio is generally negative, but response of dividend yield ratio to the one standard deviation shock in price is generally positive.

At the final step, by variance decomposition it is determined that how many of the changes in the selected variables are caused by themselves and how many of the changes are caused by the other variables, and results are given at Table 3 .

Table 3. Variance Decomposition Results*

\begin{tabular}{|c|c|c|c|c|c|}
\hline \multicolumn{3}{|c|}{ Variance Decomposition of D(AKBNK) } & \multicolumn{3}{|c|}{ Variance Decomposition of D(HALKB_PE) } \\
\hline $\mathrm{D}(\mathrm{AKBNK})$ & AKBNK_DY & AKBNK_PE & D(HALKB) & HALKB_DY & D(HALKB_PE) \\
\hline 57.948 & $31.05 \overline{4}$ & 10.999 & 4.943 & $36.51 \overline{2}$ & 58.545 \\
\hline \multicolumn{3}{|c|}{ Variance Decomposition of AKBNK_DY } & \multicolumn{3}{|c|}{ Variance Decomposition of ISCTR } \\
\hline $\mathrm{D}(\mathrm{AKBNK})$ & AKBNK_DY & AKBNK_PE & ISCTR & ISCTR_DY & ISCTR_PE \\
\hline 26.7342 & & $4.2024 \overline{4} 5$ & & $4.78 \overline{7}$ & $11.0 \overline{69}$ \\
\hline \multicolumn{3}{|c|}{ Variance Decomposition of AKBNK_PE } & \multicolumn{3}{|c|}{ Variance Decomposition of ISCTR_DY } \\
\hline $\mathrm{D}(\mathrm{AKBNK})$ & AKBNK_DY & AKBNK_PE & & & ISCTR_PE \\
\hline 28.361 & & $53.61 \overline{8}$ & & & \\
\hline \multicolumn{3}{|c|}{ Variance Decomposition of D(GARAN) } & \multicolumn{3}{|c|}{ Variance Decomposition of ISCTR_PE } \\
\hline GARAN & D(GARAN_DY) & GARAN_PE & & & ISCTR_PE \\
\hline 47.161 & & & 9.631 & & 58.4 \\
\hline \multicolumn{3}{|c|}{ Variance Decomposition of GARAN_DY } & \multicolumn{3}{|c|}{ Variance Decomposition of D(VAKBN) } \\
\hline GARAN & D(GARAN_DY) & GARAN_PE & $\mathrm{D}(\mathrm{VAKBN})$ & VAKBN_DY & VAKBN_PE \\
\hline 2.956 & & & 44.803 & & \\
\hline \multicolumn{3}{|c|}{ Variance Decomposition of D(GARAN_PE) } & \multicolumn{3}{|c|}{ Variance Decomposition of VAKBN_DY } \\
\hline GARAN & D(GARAN_DY) & GARAN_PE & $\mathrm{D}(\mathrm{VAKBN})$ & VAKBN_DY & VAKBN_PE \\
\hline 1.057 & 20.605 & $78.33 \overline{8}$ & 3.359 & $84.04 \overline{9}$ & $12.59 \overline{2}$ \\
\hline \multicolumn{3}{|c|}{ Variance Decomposition of D(HALKB) } & \multicolumn{3}{|c|}{ Variance Decomposition of VAKBN_PE } \\
\hline $\mathrm{D}(\mathrm{HALKB})$ & HALKB_DY & D(HALKB_PE) & $\mathrm{D}(\mathrm{VAKBN})$ & & VAKBN_PE \\
\hline 61.101 & & 19.796 & & & \\
\hline \multicolumn{6}{|c|}{ Variance Decomposition of HALKB_DY } \\
\hline D(HALKB) & HALKB_DY & D(HALKB_PE) & & & \\
\hline 8.86 & $78.1 \overline{5}$ & & & & \\
\hline
\end{tabular}

* Table shows average of 10-month period.

Variance decomposition results, indicates that changes in the variables are generally caused by themselves. Approximately $95 \%$ percentage of the changes in GARAN dividend yield ratio, approximately $84 \%$ percentage of the changes in ISCTR price and approximately $63 \%$ percentage of the changes in VAKBN price-earnings ratio are caused by themselves. However, the source of the changes in some of the variables is changes in other variables. For example, approximately $31 \%$ percentage of the changes in AKBNK stock price is caused by dividend yield ratio; approximately $44 \%$ percentage of the changes in GARAN stock price is caused by price-earnings ratio; approximately $36 \%$ percentage 
of the changes in HALKB price-earnings ratio is caused by dividend yield ratio; approximately $32 \%$ percentage of the changes in ISCTR price-earnings ratio is caused by dividend yield ratio and approximately $36 \%$ percentage of the changes in VAKBN stock price is caused by price-earnings ratio.

\section{Conclusion}

In the study it is aimed to analyze the relationships between price, price-earnings ratio and dividend yield ratios belong to 5 banks listed at BIST Banking sub-sector in detail. In line with this purpose, by the analyses made with VAR models it is determined that there are relationships in different dimensions between the stated variables. The results present information to the literature in theoric and to the security analysts and individual investors that they can use in practice.

When the causality test results obtained from the analyses are evaluated together, it is determined that the price-earnings and dividend yield ratios are cause of the changes in the stock price in general. Besides being consistent with the literature, this result shows that stock price changes are predictable by price-earnings ratio and dividend yield ratio. Also, the fact that both ratios are simply computable provides a significant advantage especially for the individual investor. In this context, by using stated ratios investors who are interested in stocks listed at BIST Banking sub-sector may take long or short position and provide return. On the other hand, high or low values of these ratios provide important information in terms of investment decisions. Especially, high dividend yield ratio indicates that conditions are suitable for increases in stock price and low dividend yield ratio indicates that conditions are suitable for decreases in stock price.

Results of impulse-response function prove that the variables response negatively to the shocks occurred in stock price and ratios. This result shows the sensitivity of the investors to the changes in price and dividend in buy and sell decisions. Also, positive response of stock price to the shocks in price-earnings ratio reveal that investors can invest especially based on the price-earnings ratio. On the other hand, according to the variance decomposition results dividend yield ratio has effect on price-earnings ratio and price-earnings ratio has effect on stock price.

Another important finding is that there is no interrelation between dividend yield and price-earnings ratios. This situation shows that dividend distribution decisions do not reflect on price-earnings ratio. Banks have had to keep their profits as internal financing in their balance sheets as a result of implementations of Banking Regulation and Supervision Agency (BDDK) that is the authority of the Turkish banking system. Findings can be interpreted as the fact that the implementation is accepted by the market actors too as well as that investors are focused on earnings per share of the company but they are insensitive to the decisions about internal financing.

In further studies, it is thought that investigating the relationships between the financial ratios by asymmetric impulse response functions or asymmetric causality test will present valuable information to the stock investors.

\section{Acknowledgements}

Earlier version of this study was presented in EconWorld2017@Paris Conference, Paris, France, July 25-27, 2017.

\section{References}

Al-Mwalla, M., Al-Omari, A. M., \& Ayad, F. (2010). The Relationship between P/E Ratio, Dividend Yield Ratio, Size and Stock Returns in Jordanian Companies: A Co-integration Approach. International Research Journal of Finance and Economics, 49, 87-103.

Al-Shubiri, F. N. (2010). Analysis the Determinants of Market Stock Price Movements: An Empirical Study of Jordanian Commercial Banks. International Journal of Business and Management, 5(10), 137-147. https://doi.org/10.5539/ijbm.v5n10p137

Aras, G., \& Yilmaz, M. K. (2008). Price-Earnings Ratio, Dividend Yield, and Market-To-Book Ratio To Predict Return on Stock Market: Evidence From the Emerging Markets. Journal of Global Business \& Technology, 4(1), 18-30.

Arslan, M., \& Zaman, R. (2014). Impact of Dividend Yield and Price Earnings Ratio on Stock Returns: A Study Non-Financial listed Firms of Pakistan. Research Journal of Finance and Accounting, 5(19), 68-74.

Basu, S. (1977). Investment Performance of Common Stocks in Relation to Their Price-Earnings Ratio: A Test of the Efficient Market Hypothesis. The Journal of Finance, 32(3), 663-682. https://doi.org/10.1111/j.1540-6261.1977.tb01979.x

Bhadu, S. K., \& Warne, D. P. (2009). Parametric Determinants of Price-Earnings Ratio in Indian Capital Markets. The IUP Journal of Applied Finance, 15(9), 63-82.

Bhargava, V., \& Malhotra, D. K. (2006). Do Price-Earnings Ratios Drive Stock Values? The Journal of Portfolio Management, 33(1), 86-92. http://doi.org/10.3905/jpm.2006.661379

Carlson, J. B., Pelz, E. A., \& Wohar, M. E. (2002). Will Valuation Ratios Revert to Historical Means? The Journal of 
Portfolio Management, 28(4), 23-35. https://doi.org/10.3905/jpm.2002.319851

Delen, D., Kuzey, C., \& Uyar, A. (2013). Measuring firm performance using financial ratios: A decision tree approach. Expert Systems with Applications, 40(10), 3970-3983. https://doi.org/10.1016/j.eswa.2013.01.012

Dickey, D. A., \& Fuller, W. A. (1981). Likelihood ratio statistics for autoregressive time series with a unit root. Econometrica, 49(4), 1057-1072. https://doi.org/10.2307/1912517

Durré, A., \& Giot, P. (2007). An international analysis of earnings, stock prices and bond yields. Journal of Business Finance \& Accounting, 34(3-4), 613-641. https://doi.org/10.1111/j.1468-5957.2007.02010.x

Gujarati, D. N., \& Porter, D. C. (2009). Basic econometrics (2nd ed.). New York, NY. McGraw-Hill International Edition.

Gupta, R., \& Modise, M. P. (2012). Valuation Ratios and Stock Return Predictability in South Africa: Is It There? Emerging Markets Finance and Trade, 48(1), 70-82.

Lutfi, M., \& Arsitha, J. (2016). The Analysis of Factors Affecting Price Earnings Ratio on the Company Shares Registered in Jakarta Islamic Index. Academic Journal of Economic Studies, 2(3), 55-63.

Lütkepohl, H. (2005). New Introduction to Multiple Time Series Analysis. http://doi.org/10.1007/978-3-540-27752-1

Omran, M., \& Ragab, A. (2004). Linear Versus Non-linear Relationships Between Financial Ratios and Stock Returns: Empirical Evidence from Egyptian Firms. Review of Accounting and Finance, 3(2), 84-102. https://doi.org/10.1108/eb043404

Phillips, P. C. B., \& Perron, P. (1988). Testing for a unit root in time series regression. Biometrika, 75(2), 335-346. https://doi.org/10.1093/biomet/75.2.335

Sezgin, F. H. (2010). An Empirical investigation of the relationship among P/E Ratio, stock return and dividend yiels for Istanbul Stock Exchange. International Journal of Economics and Finance Studies, 2(1), 15-23.

Sims, C. A. (1980). Macroeconomics and Reality. Econometrica, 48 (1), 1-48. https://doi.org/10.2307/1912017

Tse, R. Y. C. (2002). Price-Earnings Ratios, Dividend Yields and Real Estate Stock Prices. Journal of Real Estate Portfolio Management, 8(2), 107-113.

Appendix A. VAR Residual Serial Correlation LM Test Results

\begin{tabular}{cccccc}
\hline & $\begin{array}{c}\text { D(AKBNK) } \\
\text { AKBNK_DY } \\
\text { AKBNK_PE }\end{array}$ & $\begin{array}{c}\text { GARAN } \\
\text { D(GARAN_DY) } \\
\text { GARAN_PE }\end{array}$ & $\begin{array}{c}\text { D(HALKB) } \\
\text { HALKB_DY } \\
\text { D(HALKB_PE) }\end{array}$ & $\begin{array}{c}\text { ISCTR ISCTR_DY } \\
\text { ISCTR_PE }\end{array}$ & $\begin{array}{c}\text { D(VAKBN) VAKBN_DY } \\
\text { VAKBN_PE }\end{array}$ \\
\hline 1 & 0.196 & 0.742 & 0.325 & 0.939 & 0.594 \\
2 & 0.437 & 0.151 & 0.844 & 0.155 & 0.140 \\
3 & 0.386 & 0.339 & 0.163 & 0.417 & 0.685 \\
4 & 0.242 & 0.804 & 0.545 & 0.169 & 0.996 \\
5 & 0.266 & 0.139 & 0.871 & 0.398 & 0.840 \\
6 & 0.536 & 0.108 & 0.500 & 0.191 & 0.782 \\
7 & 0.435 & 0.522 & 0.371 & 0.397 & 0.675 \\
8 & 0.262 & 0.862 & 0.920 & 0.729 & 0.615 \\
9 & 0.625 & 0.820 & 0.516 & 0.713 & 0.724 \\
10 & 0.810 & 0.125 & 0.732 & 0.917 & 0.623 \\
\hline
\end{tabular}

Appendix B. VAR Residual Heteroscedasticity Test Results

\begin{tabular}{ll}
\hline D(AKBNK) AKBNK_DY AKBNK_PE & 0.1006 \\
GARAN D(GARAN_DY) GARAN_PE & 0.3985 \\
D(HALKB) HALKB_DY D(HALKB_PE) & 0.3899 \\
ISCTR ISCTR_DY ISCTR_PE & 0.2172 \\
D(VAKBN) VAKBN_DY VAKBN_PE & 0.2843 \\
\hline
\end{tabular}




\section{Appendix C. Impulse Responses Functions}

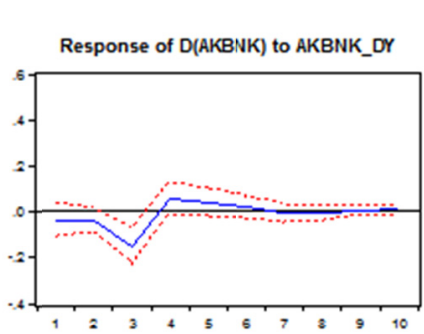

Response to Generalized One S.D. Innovations \pm 2 S.E
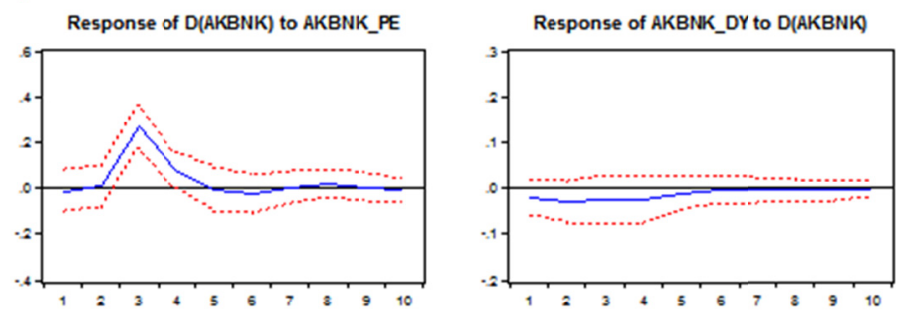

Response of AKBNK_DY to AKBNK_PE
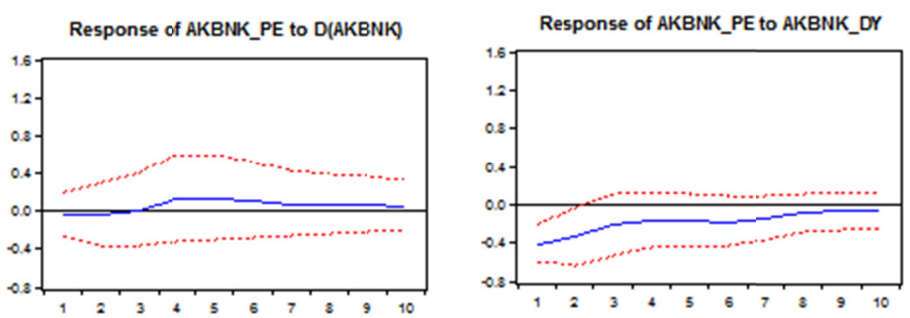

Response to Cholesky One S.D. Innovations \pm 2 S.E

Response of GARAN to D(GARAN_DY)

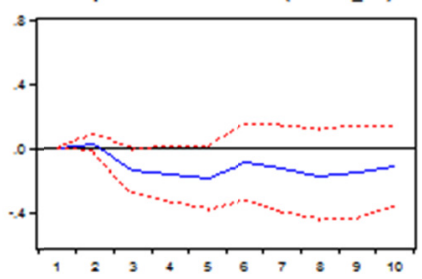

Response of GARAN to GARAN_PE

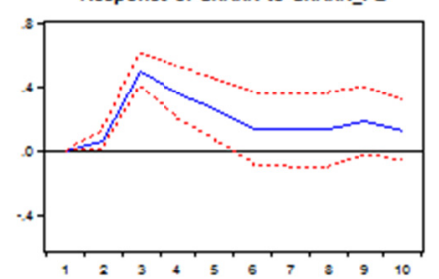

Response of D(GARAN_DY) to GARAN

Response of D(GARAN_DY) to GARAN_PE

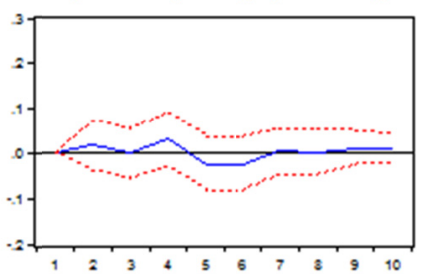

Response of GARAN_PE to GARAN
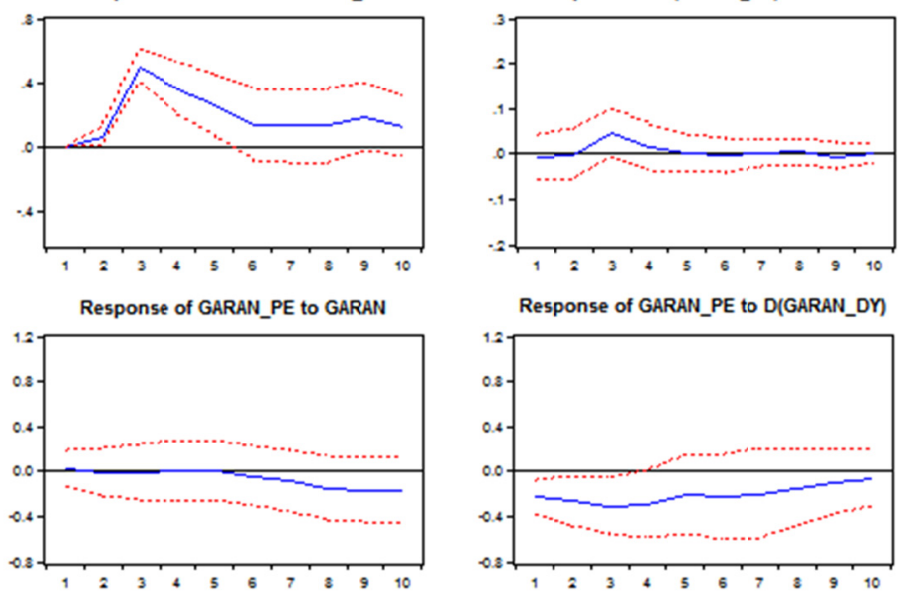

Response of GARAN_PE to D(GARAN_DY

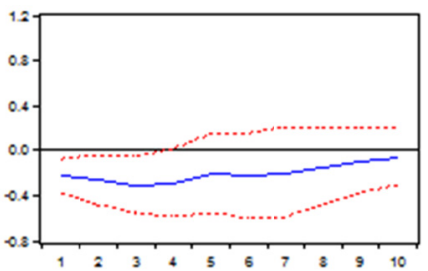

Response to Generalized One S.D. Innovations \pm 2 S.E.

Response of D(HALKB) to HALKB_DY

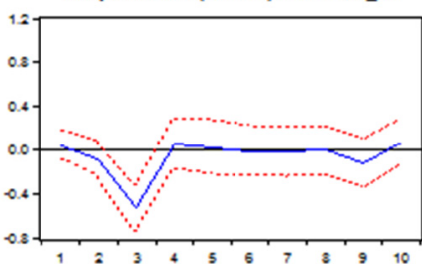

Response of D(HALKB) to D(HALKB PE

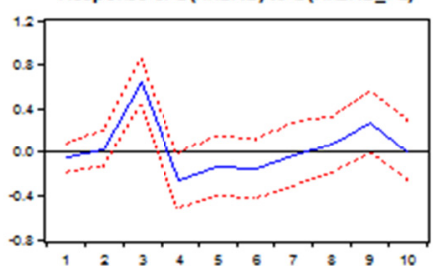

Response of HALKB_DY to D(HALKB)

Response of HALKB_DY to D(HALKB_PE)
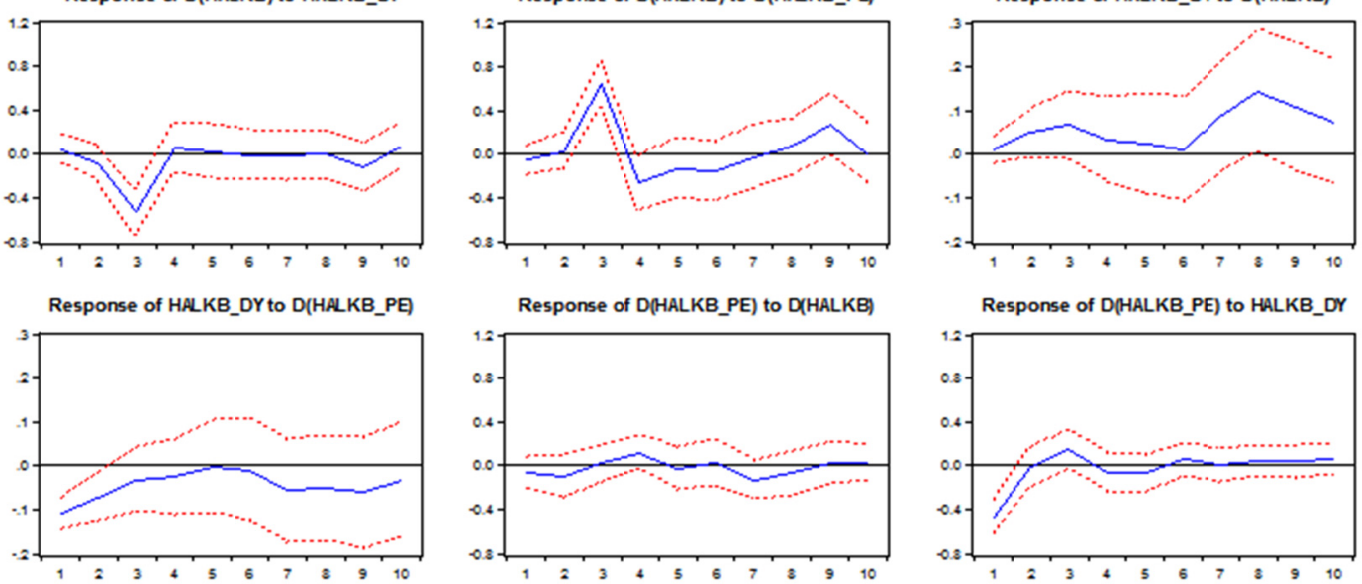


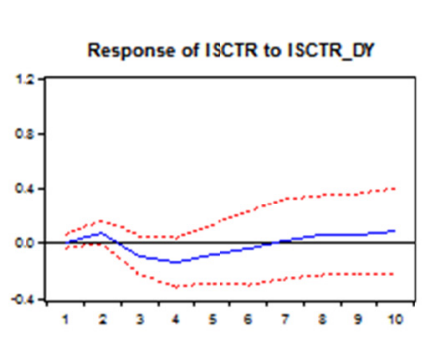

Response to Generalized One S.D. Innovations \pm 2 S.E.
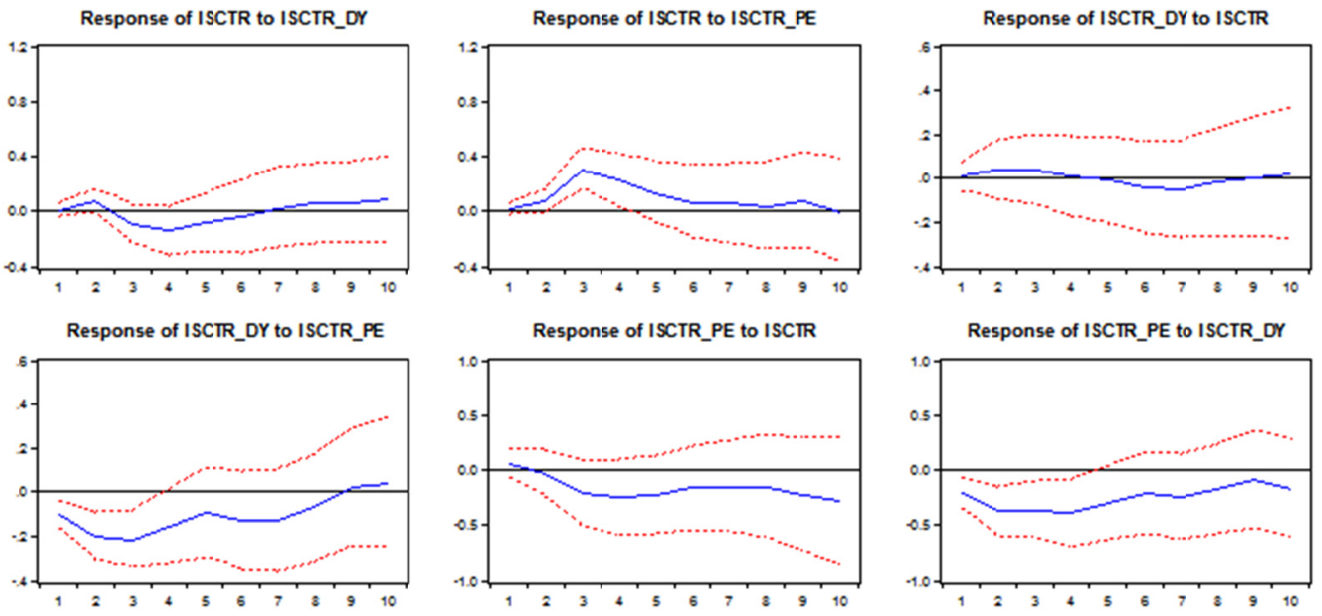

Response to Generalized One S.D. Innovations \pm 2 S.E.

Response of D(VAKBN) to VAKBN_OY

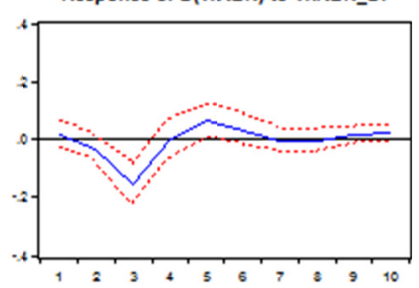

Response of D(VAKBN) to VAKBN_PE

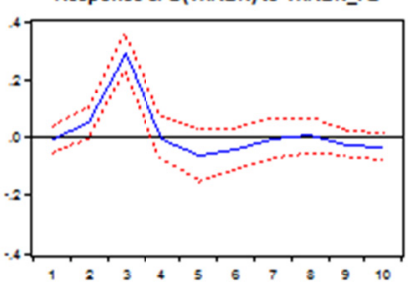

Response of VAKBN_DY to D(VAKBN)

Response of VAKBN_DY to VAKBN_PE
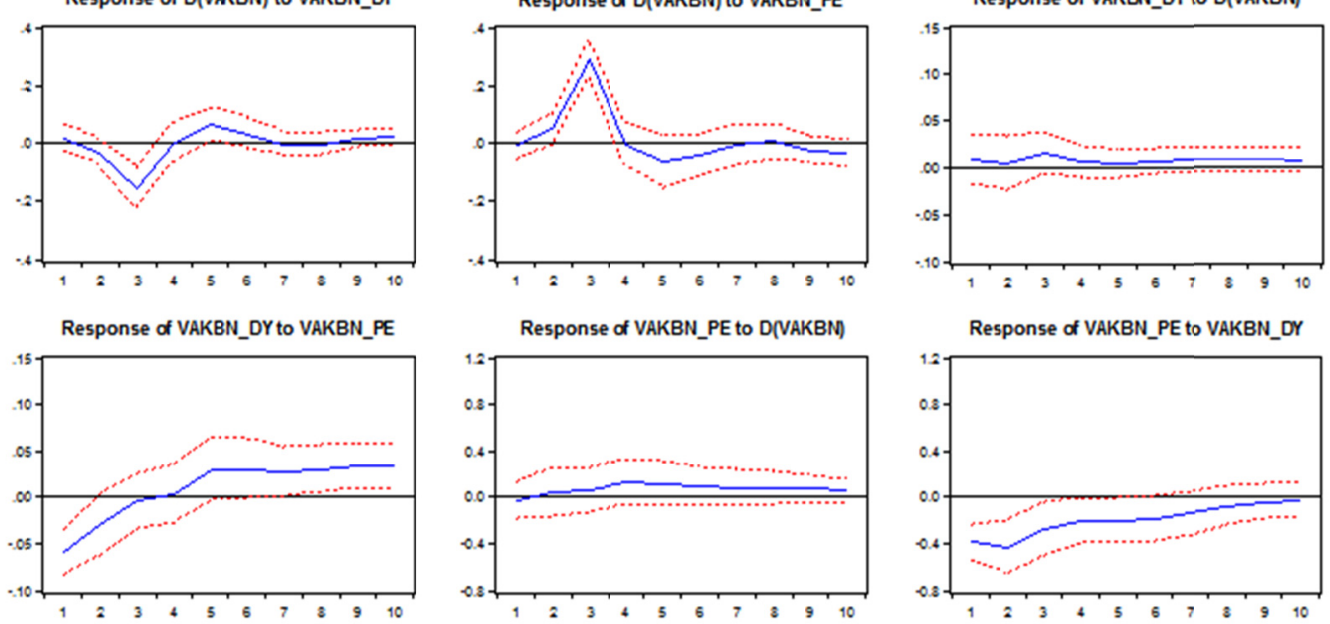

\section{Copyrights}

Copyright for this article is retained by the author(s), with first publication rights granted to the journal.

This is an open-access article distributed under the terms and conditions of the Creative Commons Attribution license which permits unrestricted use, distribution, and reproduction in any medium, provided the original work is properly cited. 